\title{
Rapid recovery of a patient with chronic balance disorders treated with combination of home-based therapy and regular physiotherapist follow-up: A case report
}

\author{
Ev tabanlı tedavi ve düzenli fizyoterapist takibi kombinasyonu ile tedavi \\ edilen kronik bir denge hastasında hızlı toparlanma: Vaka sunumu
}

\author{
Zuraida ZAINUN, Ahmadulhadi bin FAUZAN
}

ABSTRACT

Chronic balance disorder is one of the common problems that will affect people quality of life. Persistence of the problem will lead to more severe impairment in quality of life and daily activities. In this case report, a case of a 44-year old female patient, who suffered from one year long chronic balance disorder associated with the psychological symptom was presented. Dizziness started to worsen 3 months ago with severe restriction of daily activities such as cooking, house cleaning and climbing a stair. The patient had complaints of chronic balance disorder, imbalance, floating and spinning sensation, and tinnitus in her right ear. She was mainly experiencing difficulty during her daily activities when she was moving her head and phobia of crowded and small place. Balance assessment was done before and after the intervention. Malay version Vertigo symptom scale, Beck Anxiety Inventory-Malay and Beck Depression Inventory-Malay were used before and after rehabilitation. The patient then underwent home-based video module for balance rehabilitation termed as $B A L E X$ combined with physiotherapist follow up. All clinical balance assessments were normal, but positive findings were found in Fukuda test and GAN SOP test. Malay version of vertigo symptom scale (MVVSS) analysis showed that her imbalance level was in a severe range. Combination of home-based and intensive physical vestibular rehabilitation which is applied in patients with chronic balance disorders can result in rapid recovery of balance symptoms. Further research needs to be done among different types of chronic balance disorders with varying longevities in order to have a better understanding of these results.

Key words: Bal Ex Module, customized Cawthorne-Cooksey exercise, chronic balance disorder, imbalance, dizziness öz

Kronik denge bozukluğu insanların yaşam kalitesini etkileyen ortak problemlerden biridir. Sorun ne kadar uzun sürerse, yaşam kalitesindeki ve günlük aktivitelerdeki bozulma da o kadar şiddetli olur. Bu vaka sunumunda, 1 yıldır psikolojik semptomlarla ilişkili kronik denge bozukluğundan muzdarip 44 yaşında bir kadın hasta sunulmuştur. Yemek pişirme, ev temizleme ve merdiven çıkma gibi günlük aktivitelerinde ciddi kısıtlamaya neden olan baş dönmesi hissi 3 ay önce kötüleşmeye başlayan hastada kronik denge bozukluğu, dengesizlik, dalgalanma ve dönme hissi ve sağ kulakta çınlama yakınmaları mevcut idi. Hastanın yaşadığı asıl zorluk, kafa hareketlerini kullandığı günlük aktivitelerini yapmak ve kalabalık ve küçük yer fobisi olmasıydı. Denge değerlendirmesi tedavinin öncesinde ve sonrasında yapıldı. Rehabilitasyonun öncesi ve sonrasında Malay versiyonu vertigo semptom ölçeği, Beck ankisyete/kaygı envanteri-Malay ve Beck depresyon envanteriMalay uygulandı. Hastaya denge rehabilitasyonu için BAL EX olarak adlandırılan ev tabanlı video modülü, fizyoterapist takibinde uyguladı. Tüm klinik denge değerlendirmeleri sonuçları normaldi, fakat Fukuda testinde ve GAN SOP testinde pozitif sonuçlar elde edilmiştir. Malay versiyonu vertigo semptom skalası analiz sonucu hastanın dengesizlik seviyesinin ciddi aralıkta olduğunu göstermiştir. Kronik denge bozukluğu olan hastalara uygulanan ev tabanlı tedavi ve yoğun fiziksel vestibüler rehabilitasyon kombinasyonu tedavisi denge semptomlarında hızlı düzelme sağlayabilir. Bu sonuçları daha iyi anlayabilmek için farklı tipte ve sürede kronik denge bozukluklarının araştırılmasına gereksinim vardır.

Anahtar kelimeler: Bal Ex Modülü, kronik denge bozukluğu, özelleştirilmiş Cawthorne-Cooksey egzersizi
INTRODUCTION

Maintenance of normal balance system is essential to pursue normal activities in daily life. Various signs and symptoms have been detected among patients with balance disorders. Normal control of body balance and normal eye movements are involved in normal integrated systems of vestibular organ and

Received: 03.01.2017

Accepted: 28.06.2017

Audiology Programme, School of Health Sciences, Health Campus, Universiti Sains Malaysia, 16150 Kota Bharu, Kelantan, Malaysia

Yazışma adresi: Zuraida Zainun, Department of Audiology, School of Health Sciences, Health Campus University Sains Malaysia, 16150 Kota Bharu, Kelantan, Malaysia

e-mail: drzuraida@yahoo.com 
brain. In order to have normal postural control, people need the normal functioning of the eye, vestibular organ, brain and healthy proprioception. Any injury or abnormality in these systems will present with clinical symptoms of balance disorder such as imbalance, nausea, vomiting, and vertigo etc. The ageing process is one of the factors that can weaken or minimize this balance system (Soto-Varela et al. 2016). There are various etiologic factors for vestibular disorder that can be more deteriorated with the contribution of adverse genetic and environmental influences (Vestibular Disorders Association, 2016).

Vertigo is one of the common symptoms among patients with vestibular dysfunction and one of the familiar complaints seen in an emergency clinic. Several studies have showed that the prevalence of vertigo was relatively higher (1-10\%) (Vanni, S. et al. 2015). Some other studies have demonstrated that the prevalence of vertigo and dizziness as being around $7.4 \%$ in the general population aged between 18 to 97 years. From this specific survey, it is estimated that vestibular dysfunction is a chronic balance disorder seen in $50 \%$ of the patients in the older age group. The prevalence $(\approx 88 \%)$ of recurrent balance symptoms is very high and imposes a great impact on sufferers. There are increasing number of cases of medical leave and medical follow-up because of this chronic balance problem (Alsalman, O. et al., 2016)

Since Zainun and her colleagues (2008) had developed the first home-based video-guided exercise known as Bal Ex, it is available in ten different languages including Malay, English, Mandarin, Hokkien,
Tamil, Persian, Arabic, Nigerian, Cantonese and Spanish versions (Appendix 1). This module was adapted with permission and underwent some modifications from the original version, i.e., CCCE (Pavlou et al., 2004). Bal Ex consists of twenty movements divided into three levels (Table 1 ). While retaining the existing movements as in the original CCCE, Bal Ex has included two additional movements. The first added movement is bending down of the body at the $90^{\circ}$ position with hand touching the knee and the second movement is while sitting, bending down the body with palm, forehead, and knee touching the floor. These movements were included because they reflect the routine activities performed by Malaysians.

This physical exercise module has many advantages. Firstly, it is easy to perform as there is step by step instructions presented with audiovisual cues. Secondly, since it is home-based, the patients do not have to travel frequently to the hospital for treatment. This is also practical for patients with reduced mobility and it also offers more flexibility. Indirectly, it is also costeffective in the long run. Most importantly, Bal Ex can improve patient's balance symptoms and quality of life within a short time (less than 3 months). From our experience, most of the chronic peripheral cases showed a promising effect where they were able to feel the improvement after 2 weeks to 3 months after exercises.

\section{GAN SOP test}

Gans Sensory Organization Performance (SOP) Test is one of the simple tools to evaluate the body balance.

Table 1. Comparison between pre and post interventions.

\begin{tabular}{lll}
\hline TEST & PRE-INTERVENTION & POST-INTERVENTION \\
\hline Malay Version Vertigo Symptom Scale (MVVSS) & $42 / 56$ & $14 / 56$ \\
Beck Anxiety Inventory-Malay (BAI) & $22 / 63$ & $20 / 63$ \\
Beck Depression Inventory- Malay (BDI) & $5 / 60$ & $2 / 60$ \\
& Condition $1:$ Normal & Condition $1:$ Normal \\
GAN SOP & Condition $2:$ Normal & Condition $2:$ Normal \\
& Condition 3 : Normal & Condition $3:$ Normal \\
& Condition $4:$ Sway to right & Condition $4:$ Normal \\
& Condition $5:$ Sway to right & Condition $5:$ Normal \\
& Condition $6:$ Sway to right & Condition $6:$ Sway to left 8 second \\
& Condition $7:$ Sway to LEFT (270 degree) & Condition $7:$ Normal (Sway to LEFT 30 $\left.30^{\circ}\right)$
\end{tabular}


It is a simple test, cost-effective and only uses AIB Foam as an assessment tool. In this test, there are seven conditions that are important for the evaluation of the ability to utilize and integrate sensory input for postural control.

Depending upon the characteristic features of the cases, patients with vestibular disorders can be managed medically or surgically. However, non-medical alternatives such as physical rehabilitations have been found to be useful in overcoming vestibular difficulties. The Cawthorne-Cooksey exercise, for instance, has been shown to be beneficial in patients with chronic vestibular disorders. The newer version, Customized Cawthorne-Cooksey exercise has been found to be superior to the traditional one and effective in patients with chronic unilateral or bilateral vestibular disorders.

\section{CLINICAL CHARACTERISTICS OF THE PATIENTS}

The subject of this report was a 44 year-old female patient, who suffered from chronic balance disorders associated with anxiety disorder for nearly one year. The patient had a history of gastritis and tinnitus since 2015. Since 3 months, patient experienced dizziness, imbalance, floating sensations, self-spinning sensation, and headache. Her main difficulty was when she was in a dark room. She had phobia of crowded and small place. Balance assessment was done before and after the intervention. Malay version Vertigo symptom scale, Beck Anxiety Inventory-Malay and Beck Depression Inventory-Malay were applied before and after rehabilitation. All clinical balance assessments were normal, but positive findings were found in Fukuda test and SOP test. No significant history of hearing loss, tinnitus, and fullness of the ear, high fever, infections and head trauma was reported. Her difficulty prevented her from performing her normal daily activities.

\section{ASSESSMENT}

\section{- Pre-Intervention}

Comprehensive assessments were conducted on the patient to investigate her difficulties. Balance assessment was performed before the intervention. Malay version Vertigo symptom scale, Beck Anxiety Inventory-Malay and Beck Depression InventoryMalay were used before rehabilitation. All clinical balance assessments were normal, but positive findings were found in Fukuda test and GANS SOP test. Malay version of vertigo symptom scale (MVVSS) analysis showed that her imbalance level was in a severe range.

In GAN SOP test, the result for condition 1 to condition 3 , the patient was normal, but for condition 4 to condition 6, patient swayed to the right. In condition 7 of GAN SOP, patient swayed to the left about $270^{\circ}$. In order to gain information regarding the subjective severity of her difficulties, she was asked to fill in the 5-point Likert-type Malay Version of Vertigo Symptom Scale (MVVSS). This questionnaire was based on the Vertigo Symptom Scale (VSS) and had been translated into Malay language and validated accordingly. Her score was 42/56 and this indicated that her imbalance was at a severe level. The Beck Depression Inventory-Malay, is a 20-question multiple-choice self-report inventory, and it is one of the most widely used psychometric test for measuring the severity of depression. Her score was 5/60 which indicated that she had minimal depression. The Beck Anxiety Inventory-Malay is a 21-question multiple-choice self-report inventory that is used for measuring the severity of anxiety in children and adults. Her score was 22/63 which indicated that she had moderate anxiety.

\section{- Intervention}

The patient then underwent home-based vestibular therapy by means of structured video module of BAL EX modified by Zainun $Z$ et al. It consists of 19 different movements, including eye-head coordination, positioning, and postural movements. After giving detailed instructions, the patient was provided with a manual book containing the information about exercise and she was required to perform the exercise at home. She was also required to comply 
with all the requirements (to perform the exercise accordingly) and to report her progress on sheets provided. Patient is presently under surveillance of a physiotherapist.

\section{- Post-Intervention}

After 4 weeks of therapy, the patient's conditions were reassessed. In general, she showed great improvement in most tests. She reported subjectively that almost $55 \%$ of her balance difficulties had improved. She also noted that her posture improved and she was able to perform her routine daily activities better than before. The sensory analysis of GAN SOP test showed better outcomes. Her balance improved from condition 1 to condition 7. The MVVSS test also revealed some improvement (a score of 14/56). The Beck Depression Inventory-Malay test revealed a score of 2/60 which indicated that she had minimal depression. The Beck Anxiety Inventory-Malay test revealed a score of 20/63 which indicated that she had minimal anxiety.

\section{DISCUSSION}

In this report, we have presented a 44-year old female patient, who suffered from a 1-year-long chronic balance disorder associated with psychological symptoms. Her dizziness worsened 3 months ago with severe restriction of daily activities such as cooking, house cleaning and climbing a stair.

This study demonstrates the value of using combination of home-based and structured vestibular therapy on a patient with chronic balance problem with $55 \%$ improvement after one month.

This balance rehabilitation program showed an improvement in terms of psychological and balance symptoms in compliance with the results of other studies (Pavlou et al. 2012). The questionnaire showed an alleviation of balance, psychological symptoms. Objective GAN SOP test also showed a great improvement in term of postural control after the intervention. This study has demonstrated that chronic balance problem can be managed rapidly in a short term (within a month) without medication. Further research with greater number of patients will contribute favourably to our study results and offer a better understanding of the management of chronic balance problem.

\section{ACKNOWLEDGMENTS}

We would like to thank my patient and professionals who were involved in this study.

\section{REFERENCES}

1. Agrawal Y, Carey JP, Della Santina CC, Schubert MC, Minor IB. Disorders of Balance and Vestibular Function in US Adults. Arch Intern Med 2009;169(10):938-944.

2. American Institute of Balance (n.d.) AIB Balance Performance Foam( includes Gans Sensory Organization Performanc Test). Retrieved May 1, 2015 fom http://dizzy.com/Product_Detail. asp?id=6

3. Bath AP, Harris N, Mcewn J, et al. Effect of conductive hearing loss on the vestibulo-collic response. Clin Otolaryngol 1999;24:181-3.

4. Clark MR, Sullivan MD, Fischl M, et al. Symptoms as a clue to otologic and psychiatric diagnosis in- patients with dizziness. J Psychosom Res 1994;38(5):461-470.

https://doi.org/10.1016/0022-3999(94)90107-4

5. Cohen HS, Kimball KT. Improvements in path integration after vestibular rehabilitation. J Vestib Res 2002;12:47-51.

6. Horak F, Jones-rycewicz C, Black fo, Shumway-cook A. Effects of vestibular rehabilitation on dizziness and imbalance. Otolaryngol Head Neck Surg 1992;106:175-180.

7. Szturm T, Ireland DJ, Lessing-Turner M. Comparison of different exercise programs in the rehabilitation of patients with chronic peripheral vestibular dysfunction. J Vestib Res 1994;4:461-479.

8. Uchino $Y$, Sato $H$, Sasaki $M$, et al. Sacculocollic reflex arcs in cats. Journal of Neurophysiology 1997;77:3003-3012.

9. Wiorowski M, Eber AM, Wernert A, Gentine A. Recovery of saccular function after vestibular rehabilitation. Rev Laryngol Otol Rhinol (Bord) 2005;126(2):91-4.

10. Zainun Z. 2008 Video module of vestibular rehabilitation (unpublished).

11. Zainun Z, Zakaria MN, Sidek DS. Development of Malay Version of Vertigo Symptom Scale (MVVSS) For Clinican used. Presented at the $14^{\text {th }}$ National Conferences of Medical and Health Sciences, 1994; 21-22. 